Досліджено процес алибокого окиснення ізопропилового спирту в умовах способу каталітичної дії, що має назву аерозольний нанокаталіз. Процес проводили в реакторі із віброзрідженим шаром каталітичної системи, що складаеться із порошку каталітично активної речовини $\mathrm{Fe}_{2} \mathrm{O}_{3}$ та диспергуючого матеріалу. Дослідження проводяться з метою подальшої розробки екологічно чистого каталітичного генератора тепла, що працюе за принципами нанотехнологій. Основними факторами, за допомогою яких здійснюється керування в методі аерозольного нанокаталізу, є температура та механохімічна активація каталізатору. Саме механохімактивачія дозволяє регулювати режим віброзрідження каталітичної системи, керуючі селективністю каталітичного процесу для отримання необхідних продуктів. Модернізовано лабораторну установку для дослідження хімічних процесів методом аерозольного нанокаталізу в віброзрідженому шарі каталітичної системи під завдання глибокого каталітичного окиснення ізопропанолу. Проведено експериментальні дослідження із вивчення впливу температури на вміст оксиду вуглещю в газах окиснення, ступінь конверсї ізопропанолу та селективність процесу глибокого окиснення. Показано, що практично стовідсоткове окиснення ізопропанолу в $\mathrm{CO}_{2}$ в аерозолі наночасток оксида заліза досягається за температури, що мениа $630{ }^{\circ}$ С. При розробці майбутнъої технологї̈ це дозволить застосовувати низьколеговані сталі та зменшить витрати на устаткування. Результати роботи дозволили визначити напрямки подальших досліджень для оптимізацї̈ параметрів керування процесом окиснення ізопропилового спирту з метою його глибокого окиснення та отримання теплової енергї екологічним способом. Проведене порівняння деяких техніко-економічних показників нового процесу з технологіями, що застосовують гетеронегнно-каталітичне окиснення

Ключові слова: аерозольний нанокаталіз, механохімактивація, окиснення, ізопропиловий спирт, частота, каталітичний генератор тепла
UDC 66.091.2: 66.097

DOI: $10.15587 / 1729-4061.2019 .170488$

\section{PRINCIPLES OF THE PROGRESS OF REACTIONS INVOLVING DEEP OXIDATION OF ISOPROPYL ALCOHOL UNDER CONDITIONS OF AEROSOL NANOCATALYSIS TECHNOLOGY}

\author{
T. C. Philips \\ Postgraduate student* \\ E-mail: tcphilips@yahoo.com \\ S. Kudryavt sev \\ $\mathrm{PhD}$, Assistant Professor* \\ E-mail: sergeykudryavtsevsnu@gmail.com \\ I. GIikina \\ Doctor of Technical Sciences, Professor* \\ E-mail: irene555@i.ua, irene555@mail.ru \\ D. Korol \\ Postgraduate student* \\ E-mail: korol.danila@gmail.com \\ *Department of Chemical Engineering and Ecology \\ Volodymyr Dahl East Ukrainian National University
} Tsentralnyi ave., 59-a, Sievierodonetsk, Ukraine, 93400

use of ethanol as a fuel for KHG is promising, since it is relatively environmentally safe raw material. However, ethanol is a scarce product. Significant amounts of it serve as octane-increasing additives for petrol [2]. Creation of ethanol-based KHG can lead to a grain shortage, since most ethanols are produced of plant materials. The use of isopropanol as a fuel for KHG is promising, since this alcohol is made of propylene produced in FCC units of catalytic cracking-fluid [3]. Development of a catalytic heat generator operating on isopropanol is an urgent scientific and practical task due to excessive production of propylene in FCC units and its relative availability [4]. Application of the method of aerosol nanocatalysis (AnC) to this process is promising, as it uses micro amounts of a catalyst under conditions of their mechanical-and-chemical activation (MCA). Therefore, it will give possibility to develop KHG technology, which is more beneficial in terms of energy and economics [5]. enthalpy of combustion [1], which increases fuel consumption for achievement of the required power levels. The 


\section{Literature review and problem statement}

The process of deep oxidation of substance is a process of its complete combustion to carbon dioxide and water. The main negative factor for thermal combustion is high temperature. Incomplete oxidation produces toxic products such as nitrogen oxides and carbon monoxide. It is expedient to use catalytic oxidation to avoid such consequences. Existing KHG units have a powerful system of cleaning of exhaust gas for a case of an unexpected change in mode. Catalytic oxidation reduces reaction temperature and energy of the process activation. According to the technological characteristics, the catalytic combustion makes it possible [6]:

- to conduct the process at temperatures significantly below $1,200{ }^{\circ} \mathrm{C}$, such temperature almost excludes formation of nitrogen oxides;

- to use highly active catalysts capable to ensure completeness of the catalytic oxidation;

- to control the process selectivity.

The best catalysts for the oxidation process are compounds based on noble metals. They include platinum and palladium, their oxides and mixtures. In this case, it is possible to coat a porous carrier with platinum, as it is the most expensive metal. Thus, we can increase a specific surface of a catalyst. It is expedient to use aluminum or silica gel as a carrier, since they have certain microporosity [7].

Article [8] described the study of the oxidation of isopropyl alcohol in a microwave oven in a stationary bed of a granulated $\mathrm{Fe}_{3} \mathrm{O}_{4}$ catalyst. The article showed possibility of using of base metals as a catalyst. However, the technology consumes a large amount of catalyst.

Paper [9] described the study of the process of oxidation of isopropyl alcohol in a quartz reactor in a fixed bed of $\mathrm{NiFe}_{2} \mathrm{O}_{4}$ catalyst. Authors noted that the process of complete oxidation goes at $250{ }^{\circ} \mathrm{C}$. They also revealed that formation of acetone, as a by-product, is possible at lower temperatures $\left(130-230{ }^{\circ} \mathrm{C}\right)$. Therefore, it is necessary to maintain the reaction temperature above $250{ }^{\circ} \mathrm{C}$. A preparation of a catalyst is a separate stage of technology, which requires increased costs, since it is necessary to coat a porous carrier with nickel. The available literature describes very few studies of the deep oxidation process with the use of metal oxide catalysts. The limitation for the use of such catalysts $[10,11]$ is that application of such materials as silica, aluminum, and zirconium oxide as carriers is inefficient at temperatures above $1,000^{\circ} \mathrm{C}$.

An important point in the development of deep catalytic oxidation technology is the correct choice of suiTable catalyst under given conditions. However, existing technologies use catalysts applied on a porous carrier. They become inactive under reaction conditions after some time. A catalyst based on noble metals is active longer than a catalyst based on other metals. However, its cost is very high.

The technology of aerosol nanocatalysis (AnC) solves this problem successfully. It uses a catalyst in a fine-dispersed state (aerosol) without a carrier [5, 12]. The basis of AnC technology is creation of a catalytic system, which consists of catalyst particles and dispersing material. Chemical transformation occurs in an air-fluidized bed of a catalyst (AnCFB technology) or in a vibro-fluidized bed (AnCVB technology) of a catalytic system with continuous generation of catalyst nanoparticles in situ. According to earlier studies of AnC technology, researchers revealed the following principles for the deep oxidation process [12]:
- use of $\mathrm{Fe}_{2} \mathrm{O}_{3}$ only as a catalyst, without a carrier;

- variation of reaction temperature in the range of $400-600^{\circ} \mathrm{C}$;

- maintenance of the catalyst concentration at $5 \mathrm{~g} / \mathrm{m}^{3}$ of a reaction volume;

- implementation of equally accessible catalyst surface for reagents;

- maintenance of uniform weight- and heat exchange mode in a reactor.

The authors proposed to choose an aerosol nanocatalysis reactor with a vibro-fluidized catalyst bed. A device, which creates oscillations with an adjusTable frequency in a vertical plane, maintains such mode in a laboratory. In this case, catalyst particles become active in the reactor under the mechanical-and-chemical action of dispersing material of the catalytic system. They reach the aerosol state, which increases the specific surface. Thus, it is possible to achieve chemical reaction rates of the order of $10^{9} \mathrm{~mol}$ per catalyst weight per unit of time, which is almost $10^{6}$ times higher than reaction rates in traditional heterogeneous catalysis [12].

We compared using of a catalyst of noble metals [13] and complex chemical compounds [14]. And we can consider using of an aerosol of iron oxide catalyst as economically advantageous, since such a catalyst will be cheaper than usual catalyst applied to a carrier due to a smaller number of technological operations for its manufacture.

It is necessary to monitor scientific studies on the development of design solutions for future technology, since the main purpose of the study on the process of deep catalytic oxidation of isopropanol under conditions of aerosol nanocatalysis is to create a catalytic heat generator, which operates with high economic and ecological efficiency.

Patent [15] described the invention. It was a spiral-shaped reactor with a three-stage catalytic package based on $\mathrm{Pd}-\mathrm{Ge}-\mathrm{Al}_{2} \mathrm{O}_{3}$. Such a special design of the reactor and the complex composition of the catalyst made it possible to keep fuel in a rotating bed until its complete combustion at low temperatures.

Authors of paper [16] developed a design of a catalytic heat generator. The reactor operated on a heterogeneous catalyst based on $\mathrm{CuCr}_{2} \mathrm{O}_{4}, \mathrm{Mn}_{3} \mathrm{O}_{4}$ and $\mathrm{La}_{2} \mathrm{O}_{3}$ with a substrate based on synthetic cordierite. The catalyst completely oxidized hydrocarbon materials and their mixtures at low temperatures.

Authors of work [17] studied a reactor with an air-fluidized bed of a catalyst used as a catalytic heat generator for combustion of solid fuels (carbon-containing materials). Article [18] described a reactor with an air-fluidized bed of a granulated catalyst used as a catalytic heat generator.

Authors of paper [19] considered a technology of aerosol nanocatalysis and the use of a reactor with an air-fluidized bed of a catalyst for disposal of industrial waste of various aggregative states.

We considered the existing methods of catalytic oxidation of substances, and we noted that the study on the process of deep oxidation of isopropanol might be promising. Especially if we carry out the process applying a new technology of aerosol nanocatalysis, which will make it possible to obtain the final product in one run. Further, it is possible to apply the process of deep oxidation of isopropanol in catalytic heat generators. Currently, the field is little studied, therefore, it is promising. 


\section{The aim and objectives of the study}

The aim of this study is to identify patterns in the course of reactions of deep oxidation of isopropyl alcohol according to the technology of aerosol nanocatalysis in an apparatus with a vibro-fluidized catalyst bed. The identified patterns will give possibility to create a catalytic heat generator with enhanced economic and environmental parameters comparing to the existing processes.

We set the following tasks to achieve the objective:

- to modernize the laboratory unit of aerosol nanocatalysis for the catalytic oxidation process;

- to study the effect of temperature on the process of deep oxidation of isopropyl alcohol;

- to study the influence of intensity of mechanical-and-chemical activation on the course of the oxidation process;

- to compare certain environmental and economic parameters of the process being developed with the existing technologies.

\section{Description of a laboratory unit, methodology of the experiment and analysis of the experimental data}

Papers $[20,21]$ described the principle of operation of a reactor with a vibro-fluidized bed of catalyst in detail [20,21]. Fig. 1 shows a schematic diagram of the laboratory unit to study the process of deep oxidation of isopropyl alcohol.

The volume of the reactor was $40 \mathrm{~cm}^{3}$. It was necessary to prepare a catalytic system before the start of the experiment. The system consisted of a dispersing material (glass beads with a diameter of $0.8 \mathrm{~mm}$ ) and catalyst particles of up to 200 microns in size. The methodology of preparation of a catalytic system is the same for any process. Paper [21] described it. Next, we had to load the catalytic system into the reactor and to turn on heating. The vibrating device turned on to create a vibro-fluidized state in the reactor when the temperature reached $250^{\circ} \mathrm{C}$. The catalytic system crushed catalyst particles to the nanoscale size. Authors of $[5,20]$ noted this fact in their papers.

After reaching the planned reaction temperature, isopropyl alcohol and air went to the reactor. We carried out analytical control of exhaust gases for the content of $\mathrm{CO}$ and $\mathrm{CO}_{2}$ chromatographically. Paper [21] described the technique of gas chromatographic analysis in detail.

The first stage of the study was to determine an effect of temperature on the process of deep oxidation of isopropyl alcohol. We chose a temperature variation in the range of $400-600{ }^{\circ} \mathrm{C}$.

The second stage of the study was to investigate an influence of the oscillation frequency (frequency of mechanical-and-chemical activation) on the deep oxidation process. We chose the interval of variation of the oscillation frequency of $3-7 \mathrm{~Hz}$

We chose the intervals of variation based on earlier studies on the technology of aerosol nanocatalysis of other chemical transformations.

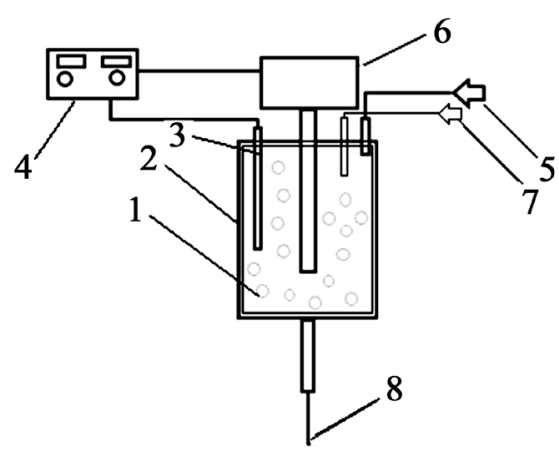

Fig. 1. Schematic diagram of the laboratory unit with the reactor with a vibro-fluidized bed of catalyst: 1 - reactor with a catalytic system; 2 - electric heater; 3 -pocket for thermocouple; 4 - device for monitoring and control of temperature and frequency of oscillation; 5 - air supply unit; 6 - device for creation of oscillations of a reactor; 7 - isopropyl alcohol supply unit; 8 - unit for sampling of exhaust gases for analysis

\section{Experimental study of the process of deep oxidation of isopropyl alcohol in a catalyst aerosol}

\section{1. The effect of temperature on the process of deep} oxidation of alcohol

Fig. 2 shows the results of study into the effect of temperature (from 400 to $560{ }^{\circ} \mathrm{C}$ ) on the course of the process of deep oxidation of isopropyl alcohol. We can see the dependence of an output of the final reaction product $\left(\mathrm{CO}_{2}\right)$ at different temperatures while maintaining the oscillation frequency at $3 \mathrm{~Hz}$ and a catalyst concentration at $5 \mathrm{~g} / \mathrm{m}^{3}$.

Fig. 2 shows that the temperature of $450{ }^{\circ} \mathrm{C}$ is a turning point between the two modes of the process (transitional and kinetic ones) for the process of deep oxidation of isopropyl alcohol according to the technology of aerosol nanocatalysis. Therefore, equations in Fig. 2 correspond to the mentioned modes. A further increase in temperature under conditions studied may possibly accelerate other chemical reactions, which reduces the output of $\mathrm{CO}_{2}$ as the main reaction product. We carried out the analytical control of $\mathrm{CO}_{2}$ chromatographically with an accuracy of $0.01 \%$ of vol. We should clearly determine the choice of controlling and controlled parameters in further studies.

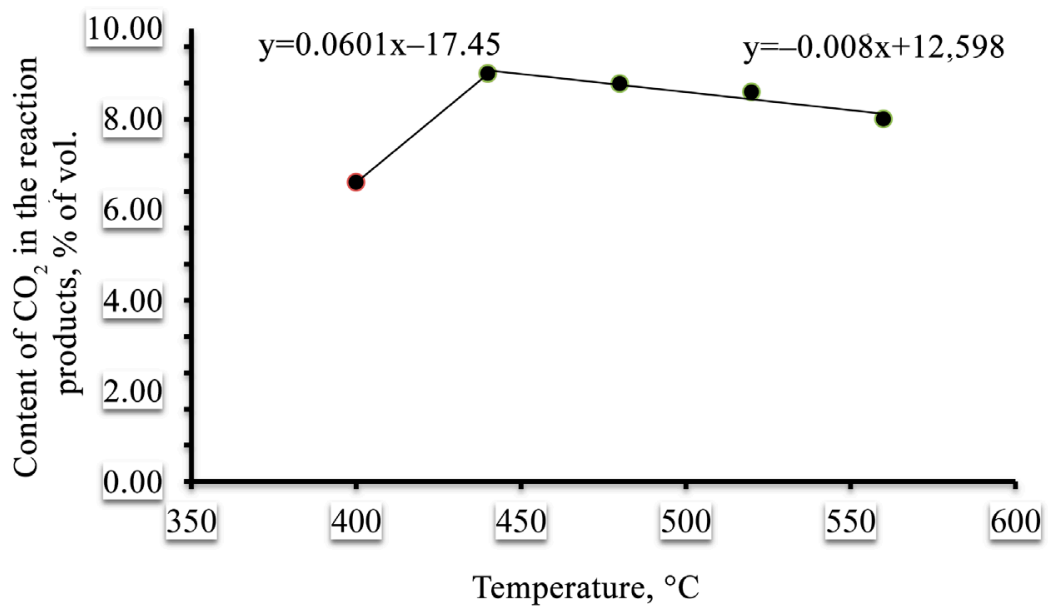

Fig. 2. Dependence of output of $\mathrm{CO}_{2}$ reaction product on temperature (frequency was $3 \mathrm{~Hz}$, catalyst concentration was $5 \mathrm{~g} / \mathrm{m}^{3}$, alcohol consumption was $0.1 \mathrm{ml} / \mathrm{min}$ ) 
Fig. 3 shows the effect of temperature on the degree of transformation of isopropyl alcohol.

The temperature measurement error was $\pm 5^{\circ} \mathrm{C}$. The deviation between the results of parallel experiments did not exceed $7 \%$

We know that catalytic reactions, in comparison with thermal reactions, are capable not only of acceleration of chemical transformation, but also of lowering its flow temperature. The experimental results in Fig. 3 confirm the assumption that the temperature of $450{ }^{\circ} \mathrm{C}$ is a transition point from one mode of the process to another one under the conditions studied. The experimental equations (Fig. 3) also confirm the above. An increase in temperature above $450{ }^{\circ} \mathrm{C}$ is inexpedient, because it leads to a decrease in the transformation of alcohol.

The assumption also confirms the dependence of the selectivity by $\mathrm{CO}_{2}$ on the temperature (Fig. 4). We can see that the process proceeds with high selectivity at the temperature of $400{ }^{\circ} \mathrm{C}$, and it is a transitional mode of the process. We noted that the selectivity decreased with an increase in temperature. Therefore, we could suggest that the process proceeded in a kinetic mode. In this case, a change in the reaction mechanism may occur and other control parameters of the reaction may appear. In addition, formation of products of sub-oxidation in a minimum amount is possible.
5. 2. The effect of oscillation frequency on the process of deep oxidation of alcohol

We obtained the study data, which reflected the influence of the oscillation frequency of the vibro-fluidized bed of the catalyst aerosol on the process of deep oxidation of isopropyl alcohol (Fig. 5). We carried out the studies at the constant temperature of $440{ }^{\circ} \mathrm{C}$ and the catalyst concentration of $5 \mathrm{~g} / \mathrm{m}^{3}$. The type of dependence showed the typical nature of the influence of mechanical oscillations on any process. The effect of the chemical transformation in AnC reactor almost did not affect the nature of the mechanical effect curve. We noted the wavelike nature of impacts. According to the previously obtained results, we maintained temperature at $440{ }^{\circ} \mathrm{C}$ and the catalyst concentration at $5 \mathrm{~g} / \mathrm{m}^{3}$ of the reaction volume. We revealed two oscillation frequencies, which showed the highest alcohol transformation. These frequencies were 3.5 and $5 \mathrm{~Hz}$. We can also assume two modes of chemical transformation: transitional one within $5 \mathrm{~Hz}$ and kinetic one within $3.5 \mathrm{~Hz}$, in the study. Perhaps that is why, there were two degrees of transformation under the conditions studied. The maximum degree of transformation obtained was 0.55 . Possibly, the supply rate of reagents was higher than the contact time in the volume studied.

Therefore, other side materials may appear in the reaction products in addition to $\mathrm{CO}_{2}$. This leads to a decrease in the degree of transformation of alcohol.

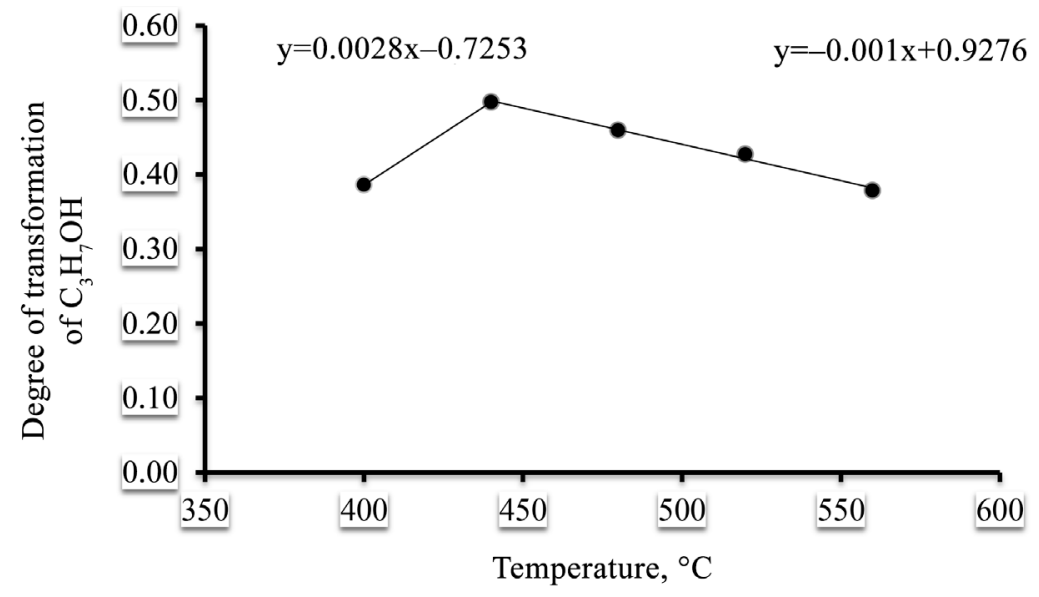

Fig. 3. Dependence of the degree of transformation of isopropyl alcohol on the temperature (frequency was $3 \mathrm{~Hz}$, catalyst concentration was $5 \mathrm{~g} / \mathrm{m}^{3}$, alcohol consumption was $0.1 \mathrm{ml} / \mathrm{min}$ )

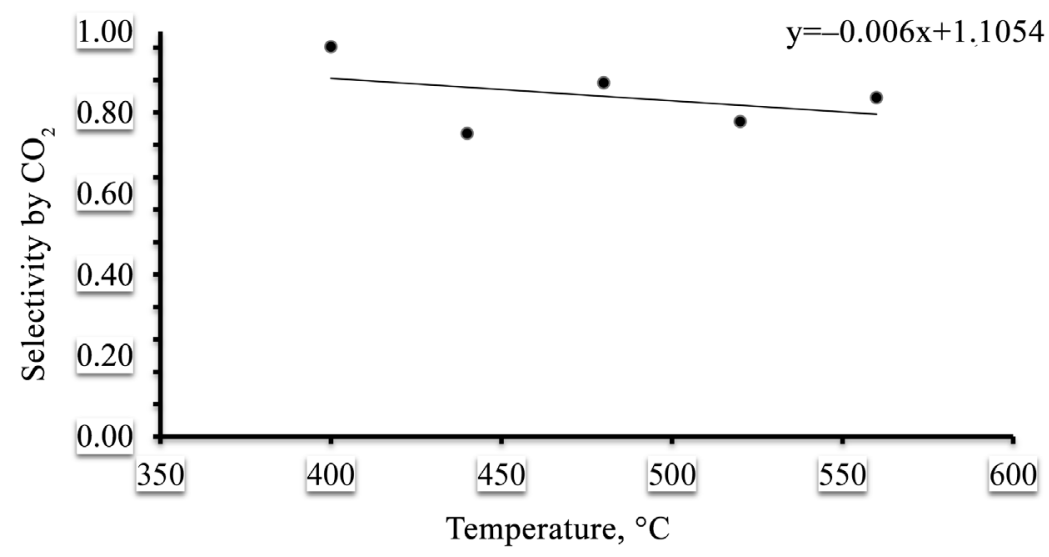

Fig. 4. Dependence of the selectivity of the oxidation process on the temperature (frequency was $3 \mathrm{~Hz}$, catalyst concentration was $5 \mathrm{~g} / \mathrm{m}^{3}$, alcohol consumption was $0.1 \mathrm{ml} / \mathrm{min}$ ) 


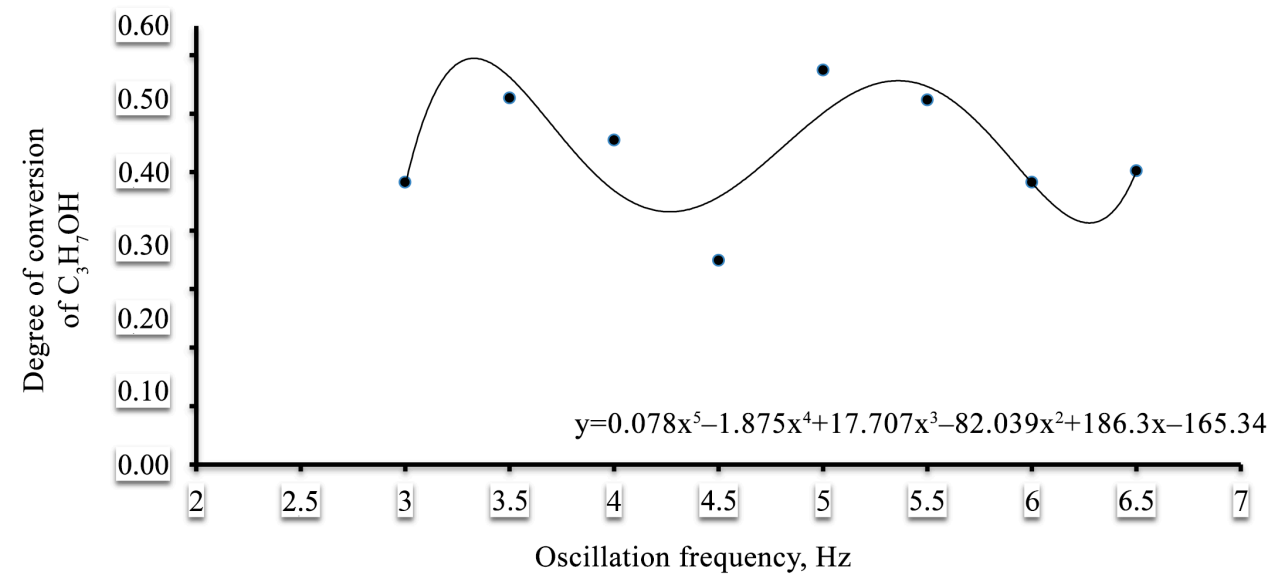

Fig. 5. Dependence of the degree of transformation of isopropyl alcohol on the oscillation frequency (temperature was $440{ }^{\circ} \mathrm{C}$, catalyst concentration was $5 \mathrm{~g} / \mathrm{m}^{3}$, consumption of alcohol was $0.1 \mathrm{ml} / \mathrm{min}$ )

5. 3. Comparative analysis of methods of the oxidation of isopropyl alcohol

Table 1 presents some technologies for the study on the oxidation of isopropyl alcohol and their basic control parameters.

Table 1

The main parameters of the process of oxidation of isopropyl alcohol

\begin{tabular}{|c|c|c|c|}
\hline Parameters & $\begin{array}{c}\text { Vibroreactor for } \\
\text { aerosol } \\
\text { nanocatalysis }\end{array}$ & $\begin{array}{c}\text { Quartz } \\
\text { reactor with } \\
\text { fixed bed of } \\
\text { catalyst [9] }\end{array}$ & $\begin{array}{c}\text { Reactor with a } \\
\text { fixed bed of cata- } \\
\text { lyst under micro- } \\
\text { wave radiation [8] }\end{array}$ \\
\hline $\begin{array}{c}\text { temperature } \\
\text { of the reac- } \\
\text { tion, }{ }^{\circ} \mathrm{C}\end{array}$ & 440 & 250 & $800-900$ \\
\hline catalyst & $\mathrm{Fe}_{2} \mathrm{O}_{3}$ & $\mathrm{Ni} / \mathrm{Fe}$ & $\mathrm{Fe}_{3} \mathrm{O}_{4}$ \\
\hline $\begin{array}{c}\text { mass of cat- } \\
\text { alyst in the } \\
\text { reactor, g }\end{array}$ & 0.0002 & 5 & 25 \\
\hline $\begin{array}{c}\text { presence of } \\
\text { a catalyst } \\
\text { carrier }\end{array}$ & $\begin{array}{c}\text { mechanical- } \\
\text { no }\end{array}$ & $\begin{array}{c}\text { required } \\
\text { preparation } \\
\text { stage of a } \\
\text { catalyst } \\
\text { required }\end{array}$ & $\begin{array}{c}\text { high microwave } \\
\text { radiation with } \\
\text { a frequency of } \\
2.450 \mathrm{MHz}\end{array}$ \\
\hline $\begin{array}{c}\text { technology } \\
\text { highlights }\end{array}$ & $\begin{array}{c}\text { and-chemical activa- } \\
\text { tion with a frequen- } \\
\text { cy of 3-6.5 Hz }\end{array}$ & \multicolumn{2}{c}{ no } \\
\hline
\end{tabular}

It was necessary to load almost a grain of catalyst into the laboratory reactor. It was of course on the verge of the accuracy of analytical balances (4th decimal place), but it was this amount that created the necessary concentration in the laboratory reactor. A dispenser supplies the required concentration of catalyst for an industrial reactor. Comparing the data in Table 1, we can note some advantages of using of aerosol nanocatalysis over the other methods. The advantages include low reaction temperature; use of a catalyst of simple composition and its rather low cost; creation of aerosol of particles with high specific surface.

\section{Discussion of results of studying the deep oxidation of isopropyl alcohol}

We noted that temperature affected the process of oxidation of isopropyl alcohol. We found that the optimum temperature was $440{ }^{\circ} \mathrm{C}$ at the constant frequency of $3 \mathrm{~Hz}$ and the catalyst concentration of $5 \mathrm{~g} / \mathrm{m}^{3}$. It was 2 times lower than, for example, for oxidation by microwave radiation. Fig. 4 shows a high selectivity of the oxidation process at $55 \%$ degree of alcohol transformation (Fig. 3) and a maximum output of $\mathrm{CO}_{2}$ (Fig. 2). The main product of the deep oxidation of alcohol was $\mathrm{CO}_{2}$.

The influence of the oscillation frequency on the oxidation process at the constant temperature of $440{ }^{\circ} \mathrm{C}$ and the catalyst concentration of $5 \mathrm{~g} / \mathrm{m}^{3}$ or two modes of chemical transformation (Fig. 5). The data showed that there was a high degree of alcohol transformation (55\%) at the oscillation frequencies of $3.5 \mathrm{~Hz}$ and $5 \mathrm{~Hz}$ under the conditions studied.

Presumably, there were modes of the chemical oxidation reaction created at these frequencies of oscillations in the reactor. Presumably, oscillation frequency of $5 \mathrm{~Hz}$ created the transitional mode, and $3.5 \mathrm{~Hz}$ - the kinetic mode. We could observe manifestation of this fact on rate and quality of chemical transformation. The surface of catalyst particles remained active. The oscillation frequency is a special control parameter in the technology of aerosol nanocatalysis with a vibro-fluidized bed. Therefore, one of the main dependencies studied on the oxidation process is the influence of the oscillation frequency.

We chose to study the process of deep oxidation of isopropyl alcohol not accidentally. We knew that isopropanol is easily susceptible to combustion due to its tendency to spontaneous combustion. It also has a high thermal effect and is readily available as a raw material, as it is a by-product in the oil refining process.

The results of the study on the technology of aerosol nanocatalysis in a fluidized bed reactor showed that iron oxide proved itself as a catalyst for deep oxidation processes. Studies of the deep oxidation in a vibro-fluidized bed reactor also showed a positive effect for iron oxide as a catalyst.

The results of the study on the process of deep oxidation of alcohol in a reactor with a vibro-fluidized bed made it possible to estimate an effect of the control parameters of the process, which, in turn, gave us possibility to determine a mode of deep oxidation of isopropyl alcohol. The obtained data made us suggest using a deep oxidation process in catalytic heat generators. We know that any technology has difficulties in its application. The proposed technology is not an exception, but its limitations relate to properties of the 
proposed design of an industrial reactor only. In general, the technology is universal and development of KHG unit under conditions of aerosol nanocatalysis will make it possible to bring chemical technology to a new level. It can be an ecologically safe project with generation of heat energy.

\section{Conclusions}

1. We modernized a system of supply of initial reagents to study the process of catalytic oxidation by aerosol nanocatalysis in the laboratory unit. Previous units were designed for gaseous reagents. Isopropyl alcohol is a liquid, so it was necessary to organize a system for dispensing a reagent into a reactor.

2. The effect of temperature revealed two modes of the oxidation process. The turning point was the temperature of $450{ }^{\circ} \mathrm{C}$. The reaction with a high degree of transformation proceeds in a transient mode at temperatures up to $450{ }^{\circ} \mathrm{C}$. An increase in temperature above $450{ }^{\circ} \mathrm{C}$ leads to the stabilization of the oxidation process. In this case, the degree of transformation reduces slightly, and the reaction is supposed to proceed in the kinetic mode. Thus, we determined that the "critical" temperature is about $440{ }^{\circ} \mathrm{C}$ and the degree of transformation is almost one. This temperature is almost 2 times lower than the temperature of the oxidation process carried out according to the other existing methods.

We observed only complete oxidation products in the reaction products when we used AnC technology. We main- tained constant parameters of reaction control, such as oscillation frequency $-3 \mathrm{~Hz}$ and catalyst concentration $-5 \mathrm{~g} / \mathrm{m}^{3}$.

3 . The results of the study on the influence of intensity of the mode of mechanical-and-chemical activation on the oxidation process showed a wave-like nature. We found modes with the degree of transformation of alcohol of $50 \%$ and modes with a degree of transformation of about $30 \%$. We obtained $50 \%$ degree of transformation of the process at the oscillation frequency of about $3.5 \mathrm{~Hz}$ and $5.5 \mathrm{~Hz}$. We obtained $30 \%$ degree of transformation under the mode of mechanical-and-chemical activation at about $4.5 \mathrm{~Hz}$ and $6.5 \mathrm{~Hz}$. The modes with a high degree of transformation also confirmed presence of two modes of the oxidation process. Presumably, the mode is close to the transitional mode at the frequency of $5.5 \mathrm{~Hz}$, and it is close to the kinetic mode at $3.5 \mathrm{~Hz}$.

4 . The results of the comparison of the main characteristics of the technology of aerosol nanocatalysis with the other methods make us suggest that the direction is promising. The obtained data on the process under study using the technology of aerosol nanocatalysis with a vibro-fluidized bed made it possible to suggest creation of an environmentally friendly KHG unit. This fact should lead to development of a new direction in the chemical industry. We determined the following key parameters for control of the process: using of iron oxide as a catalyst, its operational concentration should be $5 \mathrm{~g} / \mathrm{m}^{3}$, oxidation temperature should be $440{ }^{\circ} \mathrm{C}$ and oscillation frequency $5 \mathrm{~Hz}$. Such process produces non-toxic oxidation products, namely carbon dioxide.

References

1. Donmez E. Catalytic combustion of methanol on structured catalyst for direct methanol fuel cell. Izmir, 2011. 69 p.

2. Nulevoy sbor: v Minagropolitiki hotyat obnulit' aktsiz na etiloviy spirt. URL: http://dengi.ua/business/285126-Nylevoi-sbor-vMinagropolitiki-hotyat-obnylit-akciz-na-etilovii-spirt

3. High-purity propylene from refinery LPG / Palmer E. D., Glasgow I., Nijhawan S., Clark D., Guzman L. // Crambeth Allen Publishing Ltd. 2012. URL: https://www.digitalrefining.com/article/1000361,High_purity_propylene_from_refinery_LPG.html\#.XObYvFYzbIU

4. Prasad R., Kennedy L. A., Ruckenstein E. Catalytic Combustion // Catalysis Reviews. 1984. Vol. 26, Issue 1. P. 1-58. doi: https://doi.org/10.1080/01614948408078059

5. Glikin M. An alternative technology for catalytical processes. the aerosol nanocatalysis // Eastern-European Journal of Enterprise Technologies. 2014. Vol. 5, Issue 6 (71). P. 4-11. doi: https://doi.org/10.15587/1729-4061.2014.27700

6. Dimov S., Gasenko O. Catalytic combustion and steam reforming of hydrocarbons in microreactor // MATEC Web of Conferences. 2017. Vol. 115. P. 03011. doi: https://doi.org/10.1051/matecconf/201711503011

7. New method for regulating the activity of ABO3 perovskite catalysts / Vereshchagin S. N., Solov'ev L. A., Rabchevskii E. V., Dudnikov V. A., Ovchinnikov S. G., Anshits A. G. // Kinetics and Catalysis. 2015. Vol. 56, Issue 5. P. 640-645. doi: https://doi.org/ $10.1134 / \mathrm{s} 0023158415040199$

8. Study on the decomposition of isopropyl alcohol by using microwave/Fe3O4 catalytic system / Chang Y.-J., Lin C.-H., Hwa M.-Y. et. al. // J. Environ. Eng. Manage. 2010. Vol. 20, Issue 2. P. 63-68.

9. Tu Y.-J., Lou J. C. Isopropyl alcohol combustion on ferrite catalyst NiFe2O4 // Proc. of the 3rd IASME/WSEAS int. conf. on Energy Environment, Ecosystems and Sustainabele Development. Agios Nikolaos, 2007. P. 307-312.

10. Kinetics of high temperature methane combustion by metal oxide catalysts / McCarthy J. G., Chang Y. F., Wong V. L., Johansson E. M. // Div. Petrol. Chem. 1997. Vol. 42. P. 158-165.

11. Electrochemical Activation of Catalysis. Promotion, Electrochemical Promotion, and Metal-Support Interactions / Vayenas C. G., Bebelis S., Pliangos C., Brosda S., Tsiplakides D. Springer, 2001. 574 p. doi: https://doi.org/10.1007/b115566

12. Glikin M. A. Aerozol'niy kataliz // Teoreticheskie osnovy himicheskoy tekhnologii. 1996. Vol. 30, Issue 4. P. 430-435.

13. Spivey J. J, Roberts G. W. Catalysis // The Royal Society of Chemistry. 2004. Vol. 17. P. 1-115.

14. Catalytic Materials for High-Temperature Combustion / Zwinkels M. F. M., J r s S. G., Menon P. G., Griffin T. A. // Catalysis Reviews. 1993. Vol. 35, Issue 3. P. 319-358. doi: https://doi.org/10.1080/01614949308013910 
15. Sheludyakov E. P. Kataliticheskiy generator tepla: Pat. No. 2406954 RF. No. 2009127412/06; declareted: 16.07.2009; published: 20.12.2010. Bul. No. 35. 5 p.

16. Self-Sustained Flameless Heat Generator Based on Catalytic Oxidation of Methane or Propane-Butane Mixture for Various Object Heating Including Field Heating / Strizhak P. Y., Solovyov S. O., Trypolsky A. I., Kirienko P. I., Stoliarchuk I. L. // Nauka ta innovacii. 2016. Vol. 12, Issue 5. P. 32-46. doi: https://doi.org/10.15407/scin12.05.032

17. Catalytic thermal systems for industrial heating / Simonov A. D., Fedorov I. A., Dubinin Y. V., Yazikov N. A., Yakovlev V. A., Parmon V. N. // Kataliz v promyshlennosti. 2012. Issue 3. P. 50-57.

18. Hayes R. E., Kolackkowski S. T. Introduction to catalytic combustion. Gordon \& Breach, 1997. 681 p.

19. Glikin M. A., Kudryavtsev S. A., Glikina I. M. Improvement of production by aerosol nanocatalysis technology with mechanical activation of catalyst particles // Technology audit and production reserves. 2016. Vol. 6, Issue 3 (32). P. 4-8. doi: https://doi.org/ 10.15587/2312-8372.2016.85475

20. Glikin M. A., Glikina I. M., Kauffeldt E. Investigations and Applications of Aerosol Nano-Catalysis in a Vibrofluidized (Vibrating) Bed // Adsorption Science \& Technology. 2005. Vol. 23, Issue 2. P. 135-143. doi: https://doi.org/10.1260/0263617054037781

21. Obtaining synthesis-gas by the stone coal steam conversion using technology of aerosol nanocatalysis / Luhovskoi A., Glikin M., Kudryavtsev S., Glikina I. // Eastern-European Journal of Enterprise Technologies. 2017. Vol. 6, Issue 6 (90). P. 53-58. doi: https://doi.org/10.15587/1729-4061.2017.118396 